\title{
PRELIMINARY LABORATORY INVESTIGATION FOR THE \\ REMOVAL OF RADIOACTIVE CESIUM FROM \\ PUREX AQUEOUS WASTE SOLUTIONS
}

by

Pau Tette P. Murphy

Northwest Organization for College and University Science

and

J. S. Buckingham

Chemical Sciences Group

Research Department

Research and Engineering Division

MASTER

infringe privately owned rights.

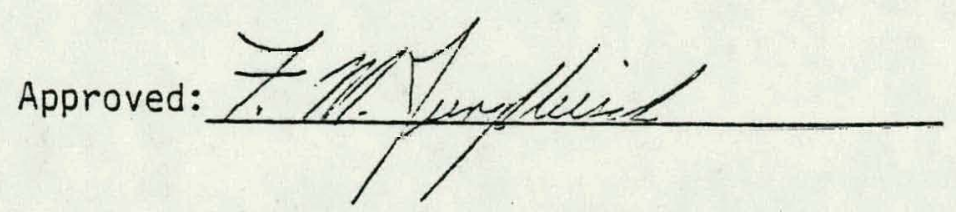

Operated for the Department of Energy by

Rockwe 11 Hanford Operations Under Contract EY-77-C-06-1030 


\section{DISCLAIMER}

This report was prepared as an account of work sponsored by an agency of the United States Government. Neither the United States Government nor any agency Thereof, nor any of their employees, makes any warranty, express or implied, or assumes any legal liability or responsibility for the accuracy, completeness, or usefulness of any information, apparatus, product, or process disclosed, or represents that its use would not infringe privately owned rights. Reference herein to any specific commercial product, process, or service by trade name, trademark, manufacturer, or otherwise does not necessarily constitute or imply its endorsement, recommendation, or favoring by the United States Government or any agency thereof. The views and opinions of authors expressed herein do not necessarily state or reflect those of the United States Government or any agency thereof. 


\section{DISCLAIMER}

Portions of this document may be illegible in electronic image products. Images are produced from the best available original document. 
PRELIMINARY LABORATORY INVESTIGATION FOR

THE REMOVAL OF RADIOACTIVE CESIUM FROM PUREX AQUEOUS WASTE SOLUTIONS

INTRODUCTION

The work reported in this document is the result of some preliminary work investigating the feasibility of removing cesium from Purex..current acid waste (CAW) by ion exchange.

"For several" years radioactive cesium has been removed from stored alkaline wastes as part of Hanford's Waste Treatment program. (1) The flowsheets are based on ion exchange techniques. A zeolite made by Linde Company, AW-500, was used for stored Purex wastes. (1,2) An organic ion exchanger, ARC-359, made by Diamond Shamrock Company, was used for the stored Redox wastes which have a higher alkalinity. $(1,3,4)\}$

Current wastes, generated by the Purex plant were treated with phosphotungstic acid (PTA) to precipitate cesium prior to the strontium solvent extraction step. $(1,5)$ The PTA precipitation step was not entirely satisfactory because the cesium losses were excessive, the chemicals were expensive, and the chemicals could not be recovered for reuse. Therefore, research was started to find a more desirable process to remove cesium from CAW prior to Purex startup. 
In 1964, Nelson, Alkire and Mercer proposed a flowsheet using the naturally occurring zeolite, clinoptilolite, for removing cesium from Purex current acid waste. (6) The process was not fully developed at the time because priorities were put on processing the very large volume of stored alkaline wastes. The PTA precipitation process did not seriously interfere with processing the alkaline wastes. Now that most of the alkaline waste has been processed, equipment would be available for processing acidic wastes through ion exchange. Ion exchange has several advantages over the PTA precipitation process. These include lower cost, lower cesium losses, reusability of the ion exchanger and the use of existing processing equipment.

\section{SUMMARY}

The laboratory work reported in this paper showed that cesium can be removed from current acid waste (CAW) by first removing strontium and rare earth by solvent extration then passing the resulting IAW solution through an ion exchange column containing a zeolite. The method for removing strontium and rare earth by solvent extraction is well documented and is not discussed here. (1) Zeolon-900, a synthetic zeolite made by Norton Company, had the highest affinity for cesium of the ion exchangers tested. Maximum cesium absorption occurred between $\mathrm{pH} 4.0$ and $\mathrm{pH} 8.5$.

The absorption of cesium from CAW or IAF was lower than that observed with 1AW. IAF is B Plant solvent extraction feed made from CAW. $1 A W$ is waste raffinate from solvent extraction.

Laboratory ion exchange column runs showed five percent cesium breakthrough occurred at 92 column volumes. Decontamination factors of $1.17 \times 10^{4}$ and $2.92 \times 10^{3}$ were found for aluminum and iron, respectively, during a laboratory column run. Sodium decontamination factors were not measured for these runs; however, Nelson, Alkaire and Mercer found the decontamination of sodium from cesium druing the processing of acid wastes was $1 \times 10^{4}$. (6) 


\section{CONCLUSIONS}

Laboratory data indicate that a flowsheet can be devised to remove cesium from current Purex acid waste. The data show that $1 \mathrm{AW}$, produced by the solvent extraction of strontium from CAW, can be routed directly to an ion exchange column for cesium removal without any intermediate treatment.

\section{EXPERIMENTAL}

Four ion exchangers were chosen for testing in the ion exchange experiments:

(1) AW-500, a zeolite from Linde Division of Union Carbide Corporation,

(2) Decalso from Ionac (emperical formula $\mathrm{Na}_{2} \mathrm{O} \mathrm{Al}(\mathrm{OH})_{3} \mathrm{XH}_{2} \mathrm{O}$ ),

(3) Duolite ARC-359, a phenolic ion exchange resin from Diamond Shamrock,

(4) Zeolon-900, a synthetic zeolite from Norton.

All solutions used for these studies were synthetic solutions whose compositions were based on chemical analysis of actual radioactive waste materials combined with flowsheet compositions. Table I shows the constitution of the three synthetic solutions examined. Because cesium selectivity is dependent (among other things) on $\mathrm{pH}$, it was treated as a variable in the solutions investigated.

Selectivily and absorbabllity of cesium by the ion exchangers was tested by batch contacts. Although batch contact studies do not provide as much information as column runs, the information can be used to quickly screen the candidate materials and conditions.

Batch contact runs were made by weighing 0.50 grams of ion exchanger in a small vial, adding five milliliters of synthetic waste solution, and gently agitating the vial for 20 to 22 minutes. The resulting solutions was decanted 
and analyzed by atomic absorption techniques. Since the contact time was the same in each case, the amount of Cs adsorbed by the resin could be measured by the following equation:

$$
K_{d}=\frac{\left(C_{0}-C\right) V}{g \cdot C}
$$

Where $K_{d}=$ Distribution constant of $C_{s}$ on the ion exchange.

$c_{0}=\quad \begin{aligned} & \text { Concentration of } C s \text { in feed solution } \\ & \text { (before contact with ion exchanger). }\end{aligned}$

$C=$ Concentration of $C s$ in product

(After contact with ion exchanger).

$v=$ Volume of solution used

(in this case $5.0 \mathrm{ml}$ ).

$\mathrm{g}=$ Grams of zeolite used (in this case $0.5 \mathrm{~g}$ ).

High $K_{d}$ values indicate that a large amount of $C_{s}$ has exchanged for the cation of the ion exchanger.

The compositions of the three synthetic solutions, used for this study are shown in Table I. Current acid waste (CAW) is the acidic waste from the Purex process after it has been partially denitrated with sugar. IAF is feed solution to the $B$ Plant solvent extraction process. It is CAW which has been diluted slightly by the addition of citric acid as a chelating agent and neutralizing to a pH of $4.6 \pm 0.2$ with sodium carbonate. IAW is the waste raffinate from the $B$ Plant solvent extraction process. This solution is similar to IAF but does not contain strontium and rare earths. It also contains some hydroxyacetic acid, a buffering agent used in the solvent extraction scrub solution. 


\section{TABLE I}

CHEMICAL COMPOSITION OF SYNTHETIC SOLUTIONS

\begin{tabular}{|c|c|c|c|}
\hline & CAW & IAF & IAW \\
\hline $\mathrm{A} 1+3$ & $0.20 \mathrm{M}$ & $0.13 \underline{M}$ & $0.11 \mathrm{M}$ \\
\hline $\mathrm{Ca}^{+2}$ & $0.002 \mathrm{M}$ & $0.0013 \mathrm{M}$ & $0.0005 \mathrm{M}$ \\
\hline $\mathrm{Cs}^{+}$ & $0.002 \bar{M}$ & $0.0013 \bar{M}$ & $0.0011 \mathrm{M}$ \\
\hline $\mathrm{Fe}^{+3}$ & $0.20 \mathrm{M}$ & $0.13 \mathrm{M}$ & $0.11 \mathrm{M}$ \\
\hline$M g+2$ & $0.002 \mathrm{M}$ & $0.0013 \mathrm{M}$ & $0.0005 \mathrm{M}$ \\
\hline $\mathrm{Na}^{+}$ & $0.70 \mathrm{M}$ & $2.39 \mathrm{M}$ & $2.0 \mathrm{M}$ \\
\hline Rare Earths +3 & $0.005 \mathrm{M}$ & $0.003 \mathrm{M}$ & $0.0025 \mathrm{M}$ \\
\hline $\mathrm{Sr}+2$ & $0.002 \bar{M}$ & $0.0013 \mathrm{M}$ & trace \\
\hline $\mathrm{H}^{+}$ & $1.00 \mathrm{M}$ & pH 4.6 & pH 4.5 \\
\hline $\mathrm{NO}_{3}^{-}$ & $2.23 M$ & $1.45 \mathrm{M}$ & $1.2 \mathrm{M}$ \\
\hline $\mathrm{SO}_{4}^{-6}$ & $0.36 \mathrm{M}$ & $0.23 \underline{M}$ & $0.20 \mathrm{M}$ \\
\hline Citrate ${ }^{-3}$ & - & $0.30 \bar{M}$ & $0.25 \bar{M}$ \\
\hline Hydroxyacetate-1 & - & - & $0.12 \mathrm{M}$ \\
\hline
\end{tabular}

Since cesium removal from alkaline waste has proved effective, it was decided to try $\mathrm{pH}$ adjustment in the basic range for comparison with acidic conditions. Adjustment of the solution $\mathrm{pH}$ was made using sodium hydroxide. A reddish-brown precipitate, presumably $\mathrm{Fe}(\mathrm{OH})_{3}$, resulted in each case upon addition of the $\mathrm{NaOH}$. To eliminate solids the solutions was centrifuged. Supernatant liquid was decanted off and contacted with the ion exchangers. For acidic IAW solutions, it was decided to try pH between 4 and 5 since the $\mathrm{pH}$ of IAW in the plant process is 4.5 .

Cesium was analyzed by atomic absorption and the distribution constants $\left(K_{d}\right)$ were calculated. The $K_{d}$ 's are shown in Table II. 


\section{TABLE II}

CESIUIN $K_{d}$ FOR SYNTHETIC IAW SOLUTIONS

\begin{tabular}{|c|c|c|c|c|c|c|}
\hline $\begin{array}{l}\text { Alkalinit, } \\
\text { or Acidits }\end{array}$ & & $\begin{array}{l}\text { Exchanger } \\
\text { Form } \\
\end{array}$ & AW-500 & $\begin{array}{c}K_{d} \\
\text { Decalso }\end{array}$ & $\begin{array}{c}K_{d} \\
\text { ARC- } 359 \\
\end{array}$ & $\begin{array}{c}K_{d} \\
\text { Zeolon-900 }\end{array}$ \\
\hline $\begin{array}{ll} & 1.6 \mathrm{M} \\
& 1.2 \overline{\mathrm{M}} \\
& 0.7 \overline{\mathrm{M}} \\
& 0.2 \overline{\mathrm{M}} \\
\mathrm{pH} & 8.5 \\
\mathrm{pH} & 5.0 \\
\mathrm{pH} & 4.5 \\
\mathrm{pH} & 4.0\end{array}$ & $\begin{array}{l}\mathrm{OH}- \\
\mathrm{OH}- \\
\mathrm{OH}- \\
\mathrm{OH}-\end{array}$ & $\begin{array}{l}\mathrm{Na}^{+} \\
\mathrm{Na}^{+} \\
\mathrm{Na}^{+} \\
\mathrm{Na}^{+} \\
\mathrm{Na}^{+} \\
\mathrm{H}^{+} \\
\mathrm{H}^{+} \\
\mathrm{H}^{+}\end{array}$ & $\begin{array}{l}46.4 \\
45.0 \\
61.1 \\
72.2 \\
83.5 \\
84.5 \\
83.8 \\
71.9\end{array}$ & $\begin{array}{l}13.8 \\
13.3 \\
20.9 \\
34.8 \\
47.1 \\
57.4 \\
50.5 \\
45.6\end{array}$ & $\begin{array}{l}64.7 \\
63.4 \\
77.8 \\
63.4 \\
11.2 \\
74.1 \\
13.9 \\
15.1\end{array}$ & $\begin{array}{r}65.9 \\
65.9 \\
77.8 \\
86.3 \\
111.1 \\
112.2 \\
109.8 \\
116.9\end{array}$ \\
\hline
\end{tabular}

Note, very favorable distribution coefficients were found in the $\mathrm{pH}$ range in which IAW and IAF fall. Zeolon-900 absorbs cesium better than AlN-500 which abosrbs cesium better than Decalso.

An option considered was to remove cesium prior to removing strontium by solvent extraction. If this optionwere used, would cesium absorb better from mildly acidic IAF containing complexants, or strong 1, acidic CAW which does not contain complexants.

Cesium $K_{d}$ for $1 A F$ solutions were determined and are shown in Table III. However, as strontium may be adsorbed by the ion exchangers, it was necessary to determine strontium $K_{d}$ also.

\section{TABLE III}

CESIUM $K_{d}$ AND STRONTIUM $K_{d}$ FOR SYNTHETIC IAF SOLUTIONS

\begin{tabular}{|c|c|c|c|}
\hline & $\mathrm{pH}$ & Cs & $d \quad s r$ \\
\hline$A W-500$ & $\begin{array}{l}4.0 \\
4.5 \\
5.0\end{array}$ & $\begin{array}{l}64.3 \\
57.9 \\
59.0\end{array}$ & $\begin{array}{l}0 \\
0 \\
0\end{array}$ \\
\hline Decal so & $\begin{array}{l}4.0 \\
4.5 \\
5.0\end{array}$ & $\begin{array}{l}43.2 \\
45.9 \\
43.2\end{array}$ & $\begin{array}{l}1.9 \\
1.5 \\
1.5\end{array}$ \\
\hline ARC-359 & $\begin{array}{l}4.0 \\
4.5 \\
5.0\end{array}$ & $\begin{array}{l}12.2 \\
11.3 \\
11.9\end{array}$ & $\begin{array}{l}3.7 \\
3.1 \\
3.3\end{array}$ \\
\hline Zeolon-900 & $\begin{array}{l}4.0 \\
4.5 \\
5.0\end{array}$ & $\begin{array}{l}93.6 \\
83.7 \\
85.4\end{array}$ & $\begin{array}{l}1.1 \\
1.1 \\
1.1\end{array}$ \\
\hline
\end{tabular}


The above results show slightly lower cesium $K_{d}$ 's with IAF than those observed with laW. The data also show that some strontium is absorbed.

The distribution of cesium and strontium from CAW. was measured at hydrogen ion concentrations higher and lower than the flowsheet value of 1 M. Results are shown in Table IV.

TABLE IV

CESIUM $K_{d}$ AND STRONTIUM $K_{d}$ FOR SYNTHETIC CAW SOLUTIONS

\begin{tabular}{|c|c|c|c|}
\hline & \multirow[b]{2}{*}{$\mathrm{H}^{+}$} & \multicolumn{2}{|c|}{$k_{d}$} \\
\hline & & Cs & $\mathrm{Sr}$ \\
\hline$A W-500$ & $\begin{array}{rl}\mathrm{pH} & 0.4 \\
& 1.09 \mathrm{M} \\
& 1.51 \overline{\mathrm{M}} \\
& 1.95 \mathrm{M}\end{array}$ & $\begin{array}{l}7.6 \\
6.5 \\
6.1 \\
4.6\end{array}$ & $\begin{array}{l}6.5 \\
6.5 \\
6.2 \\
7.3\end{array}$ \\
\hline Decalso & $\begin{aligned} & 0.4 \\
& 1.09 \mathrm{M} \\
& 1.51 \mathrm{M} \\
& 1.95 \mathrm{M}\end{aligned}$ & $\begin{array}{l}0.4 \\
0 \\
0 \\
0\end{array}$ & $\begin{array}{r}9.1 \\
9.0 \\
9.7 \\
10.3\end{array}$ \\
\hline ARC -359 & $\begin{array}{l}1.09 \mathrm{M} \\
1.51 \mathrm{M}\end{array}$ & $\begin{array}{r}4.3 \\
10.9\end{array}$ & $\begin{array}{l}9.8 \\
9.0\end{array}$ \\
\hline Zeolon-900 & $\begin{array}{rl}\mathrm{pH} & 0.4 \\
& 1.09 \mathrm{M} \\
& 1.51 \mathrm{M} \\
& 1.95 \mathrm{M}\end{array}$ & $\begin{array}{l}49.4 \\
43.6 \\
35.3 \\
29.1\end{array}$ & $\begin{array}{l}7.9 \\
8.1 \\
8.7 \\
9.3\end{array}$ \\
\hline
\end{tabular}

The data in Tables III and IV show that the strongly acidic CAW solution suppresses the absorption of cesium, but seems to improve the absorption of strontium.

The preceeding tests were made with the ion exchangers in the $\mathrm{H}^{+}$form. Tests were made to find if there was any difference in cesium selectivety between ion exchangers in the $\mathrm{H}^{+}$form or in the $\mathrm{Na}^{+}$form ion exchangers. The tests were conducted using CAW solution and two zeolites, AW-500 and Zeolon-900. The data is shown in Table $V$. 


\section{TABLE V}

\section{COMPARING CESIUM $K_{d}$ ON SODIUM FORM ZEOLITE \\ TO HYDROGEN FORM ZEOLITE}

\begin{tabular}{|c|c|c|c|c|c|}
\hline & \multirow[b]{2}{*}{$\mathrm{H}+$} & \multicolumn{2}{|c|}{ Cs K } & \multicolumn{2}{|c|}{$\operatorname{sr} K$} \\
\hline & & $\begin{array}{l}\text { Na+ } \\
\text { Form }\end{array}$ & $\begin{array}{l}\text { H+ } \\
\text { Form }\end{array}$ & $\begin{array}{l}\text { Nat } \\
\text { Form }\end{array}$ & $\begin{array}{l}\text { H+ } \\
\text { Form }\end{array}$ \\
\hline$A W-500$ & pH $\begin{array}{l}0.4 \\
1.95 \mathrm{M}\end{array}$ & $\begin{array}{r}12.1 \\
4.4\end{array}$ & $\begin{array}{l}7.6 \\
4.6\end{array}$ & $\begin{array}{l}6.0 \\
7.4\end{array}$ & $\begin{array}{l}6.5 \\
7.3\end{array}$ \\
\hline Zeolon-900 & pH $\begin{aligned} 0.4 \\
1.95 \mathrm{M}\end{aligned}$ & $\begin{array}{l}42.8 \\
29.4\end{array}$ & $\begin{array}{l}49.4 \\
29.1\end{array}$ & $\begin{array}{l}7.9 \\
9.0\end{array}$ & 9.3 \\
\hline
\end{tabular}

The above data indicate that it does not make much difference whether the zeolite is in the hydrogen form or in the sodium form prior to the loading cycle.

Batch distribution data indicates the best conditions for removing cesium from CAW would be to use IAW solution with Zeolon-900. Column studies were made

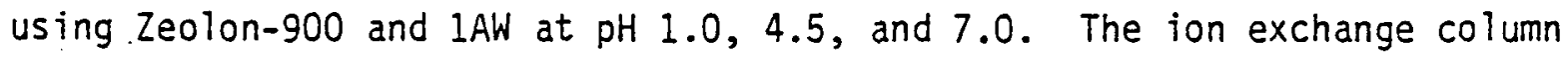
used was 1.9 centimeters in diameter, 17 centimeters high, filled with 20 milliliters of wet, settled Zeolon-900. Solution was pumped downflow through the ion exchange bed by a Fluid Metering, Inc. laboratory pump at a rate of one column volumes per hour. Effluents from the column were collected in 20 milliliter fractions by a Camag Varicol fraction collector. Each fraction represented one column volume.

The column runs consisted of five steps: (1) loading, (2) washing out interstitial feed solution with water, (3) scrubbing co-absorbed sodium from the column, (4) eluting cesium from the column, and (5) regenerating the ion exchanger to the sodium or hydrogen form.

In the first run, 50 column volumes of lAW were passed downflow through the column. The column was then washed with three column volumes of water to remove interstitial feed solution. Sodium was scrubbed from the column with 11 column volumes of $0.15 \mathrm{M}\left(\mathrm{NH}_{4}\right)_{2} \mathrm{CO}_{3}$. Cesium was eluted from the column 
with 11 column volumes of $3 \mathrm{M}\left(\mathrm{NH}_{4}\right)_{2} \mathrm{CO}_{3}-2 \mathrm{MNH} \cdot \mathrm{OH}$. Analys is of the column effluents are shown in Table VI.

The data show, that cesium breakthrough had not occurred during the loading cycle. In the processing plant the cesium ion exchange column is usually loaded to about five percent breakthrough. The data also show that we eluted less than 20 percent of the cesium loaded on the column.

Following elution the column was water washed with four column volumes of water and regenerated by passing two column volumes of $6 \mathrm{M} \mathrm{NaNO}_{3}$ through the column.

The second run consisted of loading 62 column volumes of 1 AW adjusted to $\mathrm{pH} 1.0$ onto the column. After loading the column was washed with four column volumes of water, and sodium was scrubbed from the column with 11 column volumes of $0.15 \mathrm{M}\left(\mathrm{NH}_{4}\right)_{2} \mathrm{CO}_{3}$. The column was eluted with 24 column volumes of $3 \mathrm{M}\left(\mathrm{NH}_{4}\right)_{2} \mathrm{CO}_{3}-2 \mathrm{MH}_{4} \mathrm{OH}$. Cesium analyses of the effluents are shown in Table VII.

The data indicate that cesium breakthrough had not occurred even after loading on 62 column volumes. The amount of cesium lost during loading was about 0.1 percent. Around 0.5 percent of the cesium was lost during the water wash and. another 0.2 percent was lost during the scrub step. The elution step removed 96 percent of the cesium from the column. A plot of the percent cesium remaining on the ion exchange column during the elution cycle is shown in Figure 1. 


\section{TABLE VI ,}

\begin{tabular}{|c|c|c|}
\hline Colun & n Volumes & C, ppm Cs \\
\hline & 1 & 0.00 \\
\hline & 5 & 0.04 \\
\hline & 10 & 0.06 \\
\hline & 15 & 0.06 \\
\hline & 20 & 0.07 \\
\hline & 25 & 0.07 \\
\hline & 30 & 0.07 \\
\hline & 35 & 0.07 \\
\hline & 40 & 0.07 \\
\hline & 45 & 0.07 \\
\hline & 50 & 0.07 \\
\hline Water was & h composite & 0.05 \\
\hline Scrub com & posite & 0.04 \\
\hline Elute & 1 & 0.02 \\
\hline & 3 & 0.02 \\
\hline & 5 & 0.08 \\
\hline & 7 & 5.17 \\
\hline & 9 & 63.55 \\
\hline . & 11 & 331.80 \\
\hline Elute $c$ & omposite & 52.89 \\
\hline
\end{tabular}


TABLE VII

CONCENTRATIONS OF CS IN 1AW PH 1.0 EFFLUENTS

LAW Feed 128.57 ppm Cs

Column Volumes

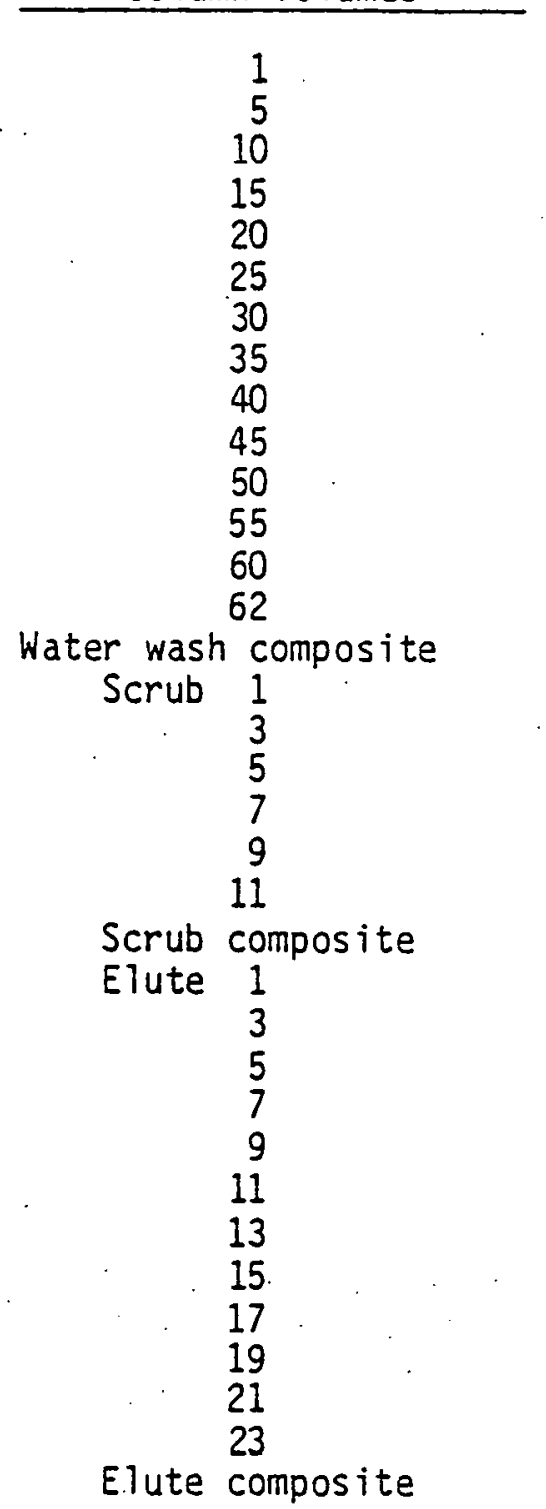

C, ppm Cs

0.06

0.12

0.13

0.13

0.12

0.12

0.12

0.12

0.12

0.12

0.13

0.12

0.12

0.12

10.10

5.50

0.29

0.46

0.52

1.43

1.90

1.50

1.62

92.4

444.4

547.42

623.10

623.10

540.69

393.90

262.44

167.81

96.90

52.48

323.45 
Decontamination factors for aluminum and iron were determined by measuring the concentration of iron and aluminum in both the feed solution and in the composited eluted product. Decontamination factors were calculated by dividing the concentration of contaminate per unit of cesium (grams per gram) in the feed solution by the concentration of contaminate per unit of cesium (grams per $\mathrm{gram}$ ) in the product solution. The results are shown in Table VIII.

\section{TABLE VIII}

IRON AND ALUMINUM DECONTAMINATION FACTORS

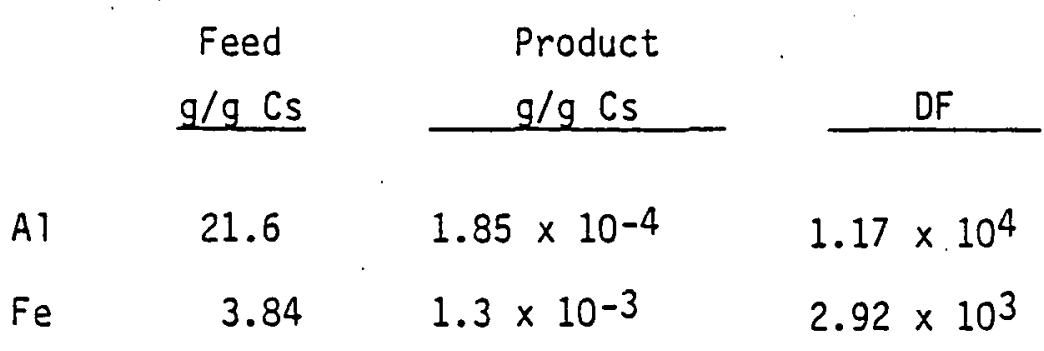

After reconditioning the column with water and $6 \mathrm{M} \mathrm{NaNO}_{3}$, the third run was made by loading 92 column volumes of $1 \mathrm{AW}$ at $\mathrm{pH}^{\prime} 7$ onto the column. The loaded column was. washed with four column volumes of water, scrubbed with 17 column volumes of $0.15 \mathrm{M}\left(\mathrm{NH}_{4}\right)_{2} \mathrm{CO}_{3}$ and eluted with 25 column volumes of $3 \mathrm{M}\left(\mathrm{NH}_{4}\right)_{2} \mathrm{CO}_{3}-2 \mathrm{M} \mathrm{NH}{ }_{4} \mathrm{OH}$. Cesium analyses of the effluents are shown in Table. IX. The ratio of the cesium concentration in the column effluents $(C)$ to the cesium concentration in the feed $\left(C_{0}\right)$ is shown plotted in Figure 2.

Plotting the cesium breakthrough curve of Run 3 on probability paper as was done in Figure 3, one can see that five percent breakthrough will occur at 92 column volumes. 
TABLE IX

CONCENTRATION OF CS IN IAW PH 7.0 EFFLUENTS

1AW Feed 132.63 ppm Cs

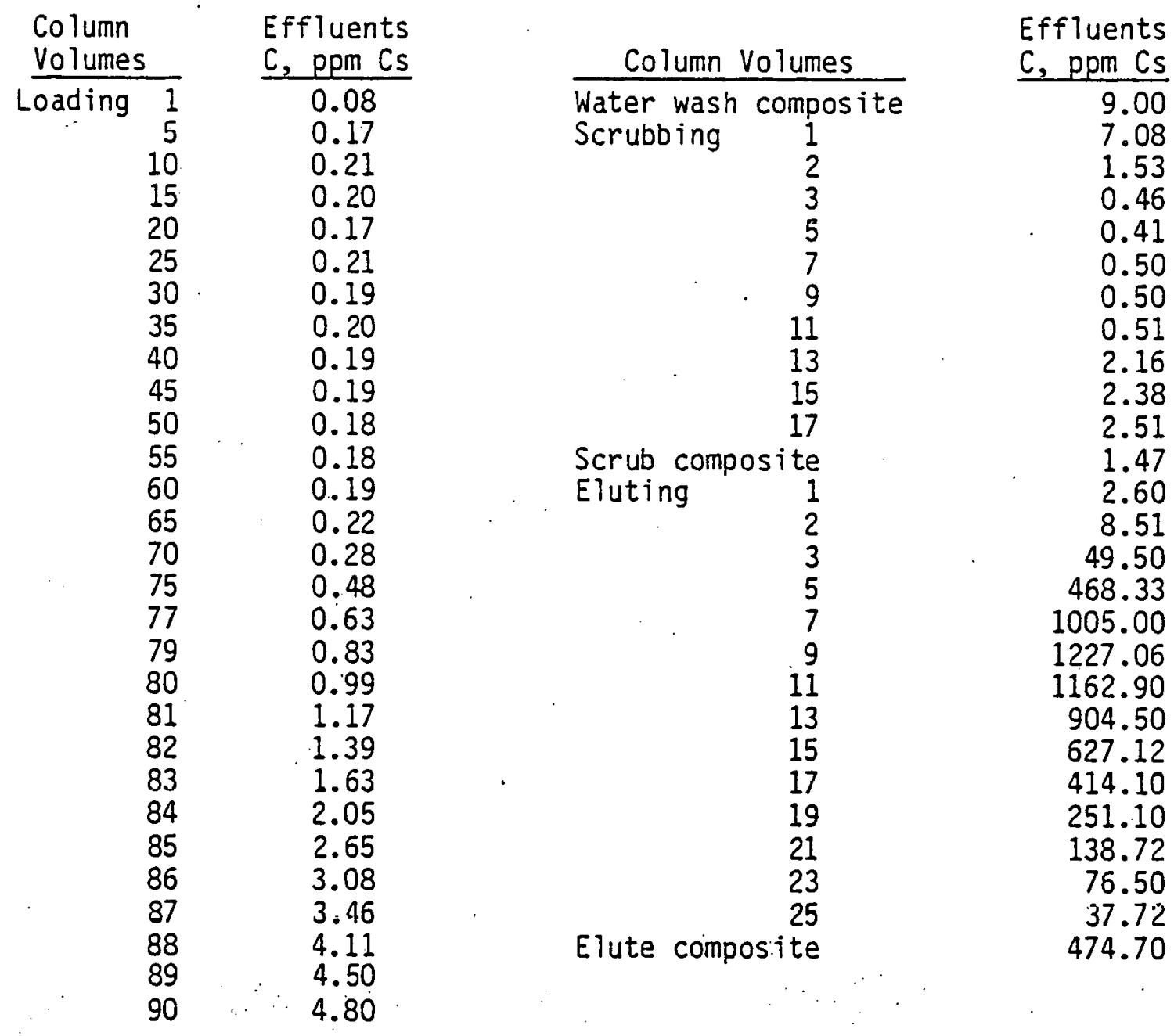




\section{ACKNOWLEDGEMENT}

We would like to thank W. I. Winters and D. E. Nelson for assistance and training with atomic absorption analyses. 


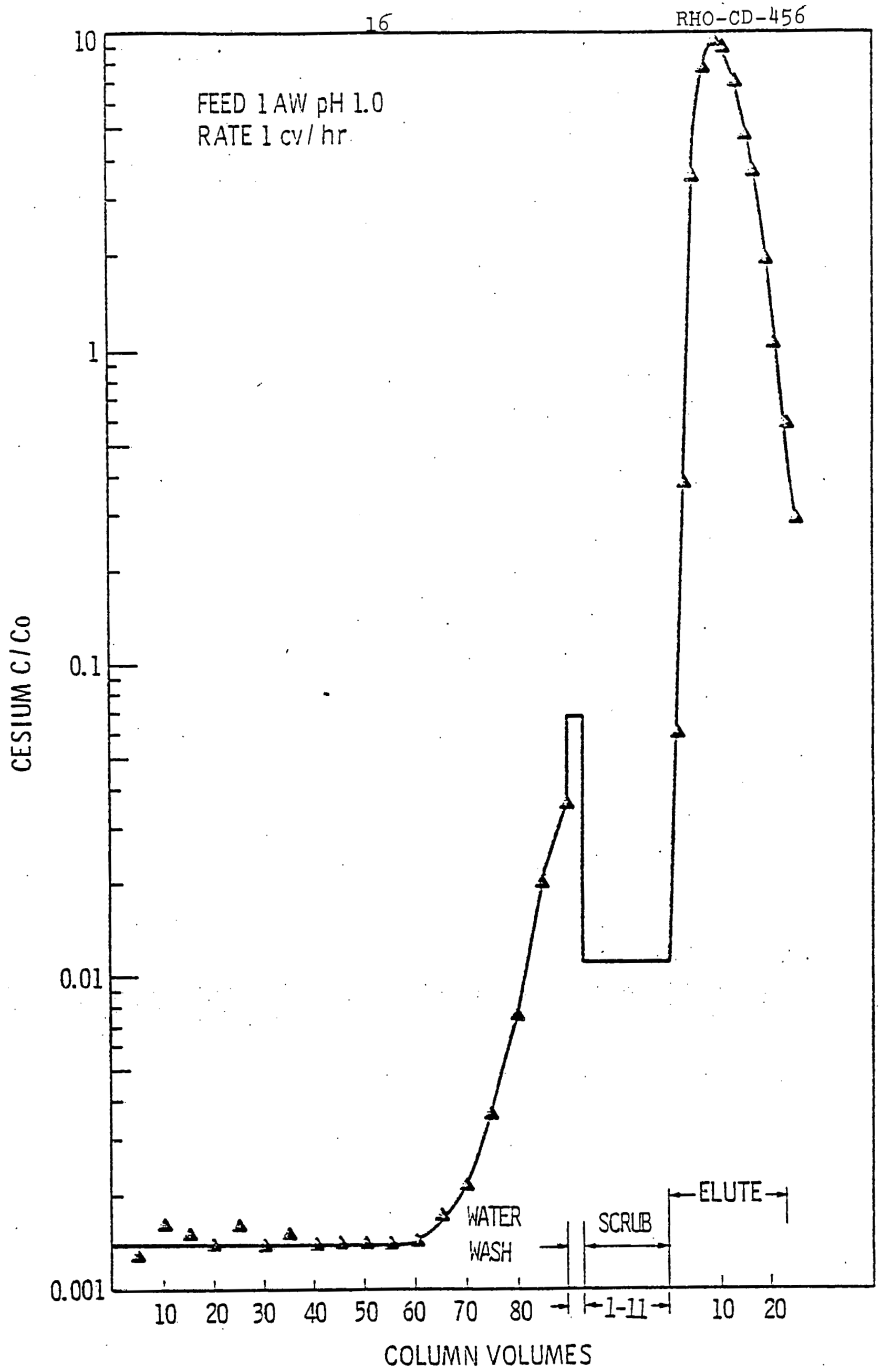




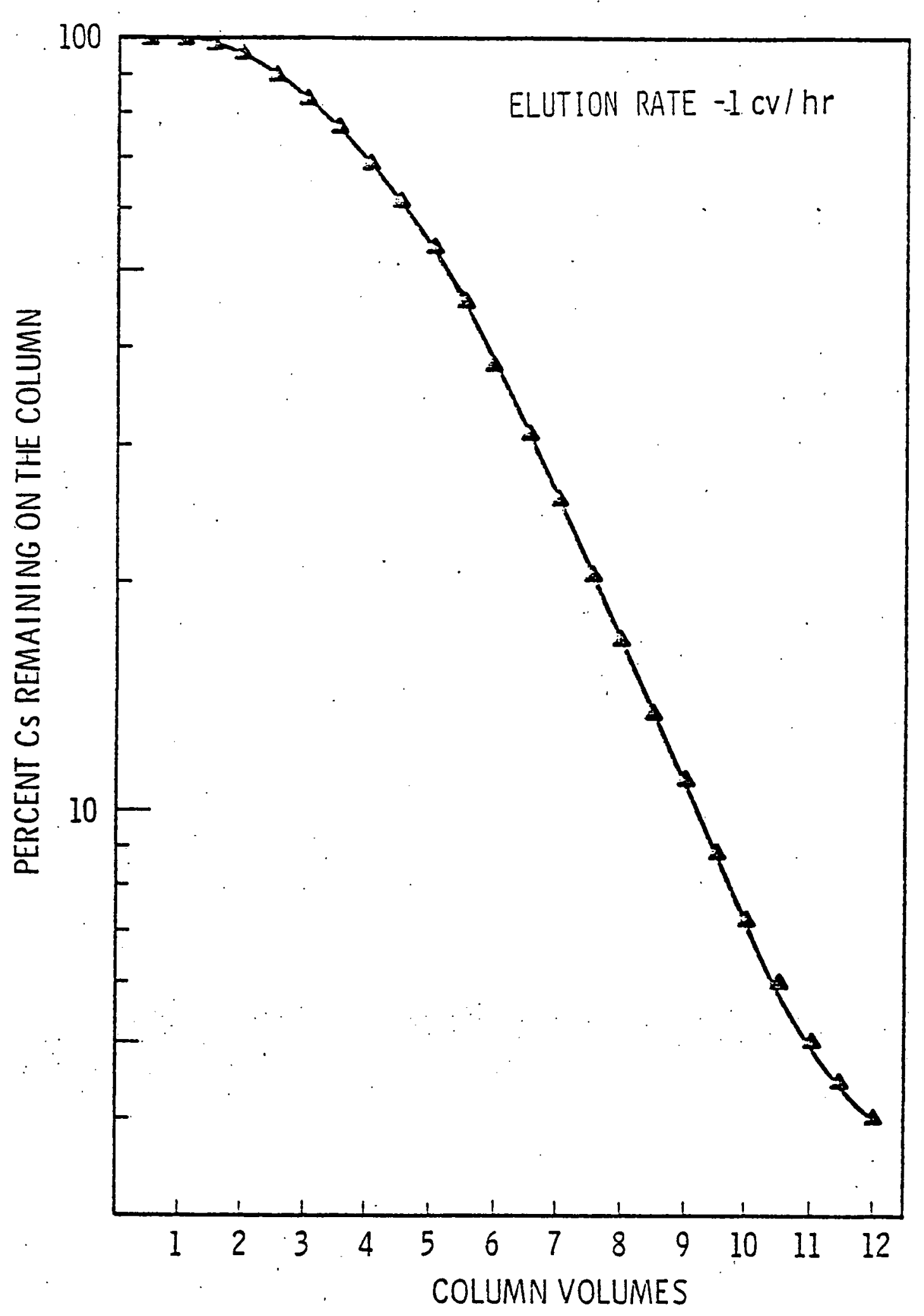

FIGURE ?

PERCENT CESIUPA REMAINING ON ZEOLON-900

ION EXCHANGE COLUMN DURING ELUTION, RUN 2 


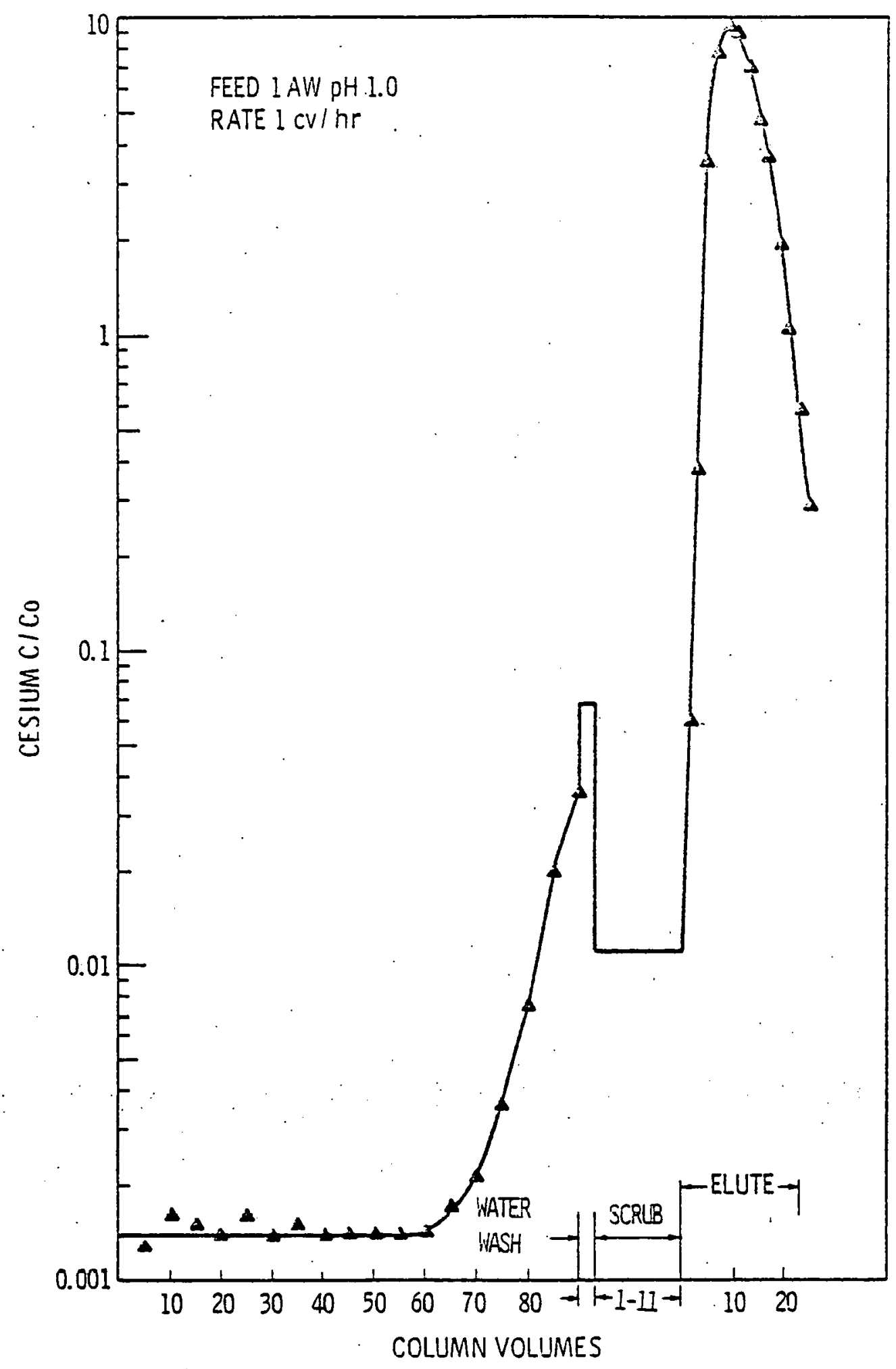

FIGURE 2

CESIUM $C / C_{0}$ OF ION EXCHANGE COLUMN EFFLUENTS RUN 3 


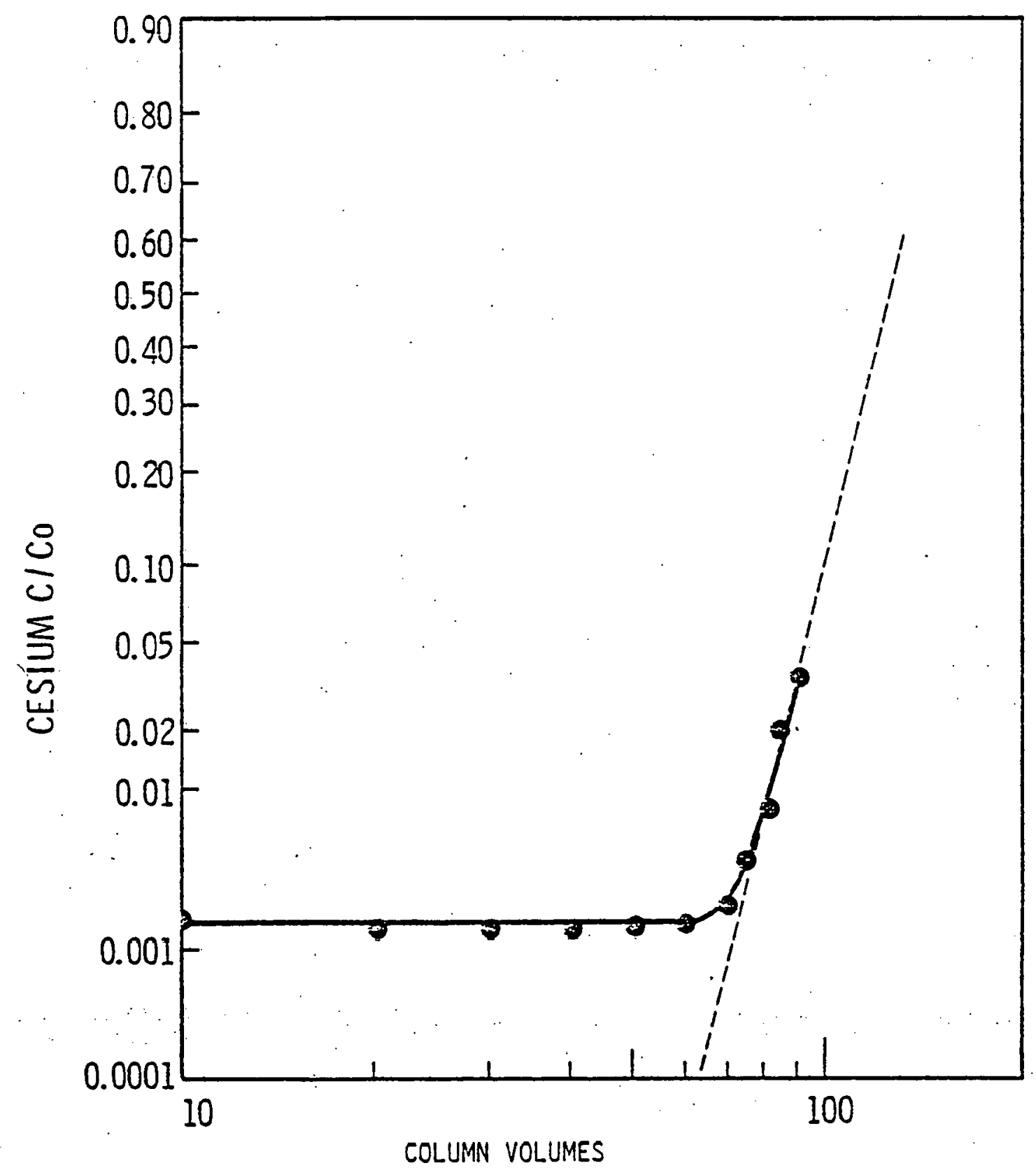

FIGURE 3 